\title{
Toward ICD-11 Implementation: Attitudes and Expectations of the Russian Psychiatric Community
}

\author{
Навстречу внедрения МКБ-11: установки и ожидания российского \\ психиатрического сообщества \\ doi:10.17816/CP80
}

\author{
(C) Maya A. Kulygina', Timur S. Syunyakov', \\ Ilya A. Fedotov ${ }^{2}$, George P. Kostyuk ${ }^{1}$ \\ ${ }^{1}$ Mental-health clinic No.1 named after N.A. Alekseev \\ Moscow, Russia; ${ }^{2}$ Psychiatry Department, Ryazan State \\ Medical University, Ryazan, Russia
}

\author{
(C) Майя А. Кулыгина', Тимур С. Сюняков', \\ Илья А. Федотов ${ }^{2}$, Георгий П. Костюк ${ }^{1}$ \\ 'Психиатрическая клиническая больница №1 им. Н.А. \\ Алексеева, Москва, Россия; ${ }^{2}$ Кафедра психиатрии, \\ Рязанский государственный медицинский университет, \\ Рязань, Россия
}

\begin{abstract}
Background. ICD-11 implementation will start in early 2022 in WHO member countries, including Russia. This process should be preceded not only by the official translation and wide distribution of ICD-11 statistical classification and diagnostic guidelines but also by clinicians' training. For recent years ICD-11 development and innovations in the diagnosis of mental disorders were in the focus of attention of mental health professionals in all over the world.
\end{abstract}

Objectives. This online survey aimed to identify the current views of the Russian psychiatric community on the upcoming implementation of ICD-11.

Methods. A survey was composed in a Google form and circulated through the website of the Russian Society of Psychiatrists and other professional networks. Statistical and narrative analysis was provided. The sample was represented by 148 psychiatrists working in inpatient or outpatient clinical settings.

Results. Expectations for the classification of mental disorders reported by the respondents were wider than the current purpose of ICD-10. In general, the Russian psychiatrists expressed their interests to forthcoming ICD-11 implementation. Positive attitudes to ICD-11 innovations were associated with the familiarity with the ICD-11 draft. Conservative or negative views were related to longer years of clinical experience. Early carrier psychiatrists were more practically oriented than 'old school' clinicians.

Conclusion. This survey may help to promote the ICD-11 by focusing on its advantages for clinical practice and develop targeted training programs.

\footnotetext{
АННОТАЦИЯ

Актуальность. Ожидается, что внедрение МКБ-11 начнется с 2022 года в странах-членах ВОЗ, включая Россию. Этот процесс предполагает не только официальный перевод статистической классификации и диагностических указаниях МКБ-11, но и соответствующую подготовку клиницистов. В последние годы разработка МКБ-11 и нововведения для диагностики психических расстройств находились в центре внимания специалистов в области психического здоровья во всем мире.
} 
Цели. Данный онлайн-опрос был проведен с целью выявления ожиданий и установок представителей российского психиатрического сообщества в преддверии внедрения МКБ-11.

Материал и методы. Опрос был составлен в Google форме и распространен через сайт Российского общества психиатров и другие профессиональные сети. Был проведен статистический и нарративный анализ ответов респондентов. Выборка была представлена 148 психиатрами, работающими в стационарных или амбулаторных клинических условиях.

Результаты. Ожидания в отношении классификации психических расстройств, о которых сообщили респонденты, были шире, чем те цели, для которых они используют МКБ-10 в своей повседневной практике. В целом российские психиатры выразили свою заинтересованность новой версией МКБ-11. Позитивное отношение к нововведениям МКБ-11 было связано со степенью осведомленности с данным проектом. Консервативные взгляды или негативное отношение были чаще типичны для специалистов с более длительным клиническим опытом. Психиатры, начинающие свою профессиональную карьеру, были более ориентированы на практическое использование новой версии МКБ, чем клиницисты "старой школы".

Вывод. Результаты опроса, отражающие распространенные мнения и взгляды отечественных клиницистов, могут быть полезны для продвижения МКБ-11. Прежде всего потребуется широкое ознакомление профессионального психиатрического сообщества с новыми указаниями данной классификации для диагностики психических расстройств, и привлечение внимания к ее преимуществам для применения в клинической практике. Важное значение имеет также разработка целевых обучающих программ с учетом разной степени готовности к вводимым изменениям.

Key words: ICD-11; ICD-10; diagnosis; clinical practice; mental disorders; attitudes; Russian Society of Psychiatrists Ключевые слова: МКБ-11; МКБ-10; диагностика; клиническая практика; психические расстройства; установки; Российское общество психиатров

\section{INTRODUCTION}

After an almost 30-year period, the World Health Organization (WHO) adopted the 11th version of the International Statistical Classification of Diseases and Related Health Problems (ICD-11) in May 2019. The transition to ICD-11 in WHO member countries is expected to begin on January 1, 2022, and may be implemented until 2027. The previous version ICD-10, which is currently up to date, was adopted by the WHO World Assembly in 1990. In Russia, ICD-10 has been officially implemented into the health care system since 1999. The development of the ICD-11 Chapter Mental, behavioural and neurodevelopmental disorders was unprecedented in its scale, multilinguistic, and multidisciplinary features, including a work of the WHO advisory and the coordination groups composed of leading specialists, the activities of the Global Clinical Practice Network, the inclusion of the ICD-11 agenda in all major international congresses, and field trials. ${ }^{1}$ Russian specialists actively participated in the revision process. The meetings of the Russian Society of Psychiatrists (St. Petersburg, 2010, 2019; Samara, 2013; Kazan, 2015) and conferences on mental health issues (Moscow, 2014, 2018, 2020, Kazan, 2021) tackled sections or discussions on ICD-11 innovations. Specific trainings have been conducted for clinicians participating in international ICD-11 field trials. ${ }^{2}$ The workshop on ICD-11 diagnostic guidelines for opinion leaders in psychiatry was organized at the Public Chamber of the Russian Federation (Moscow, 2019). The educational course "New ICD-11 guidelines for the diagnosis of mental disorders" was developed within the framework of continuous medical education in the Training and Research Center of Mental Health Clinic No. 1 named after N. A. Alexeev (Moscow, 2019). Lectures on ICD-11 were included in the program of additional professional education named as "Moscow clinician" (2020). 
However, a knowledge about ICD-11 innovations in the diagnosis of mental disorders is still insufficient in the Russian professional community. As the process of implementing ICD-10 in the Russian mental health care system was long and had some difficulties, so observing the attitudes and views of Russian clinicians prior to the start of the transition to ICD-11 may be useful.

Large-scale international surveys on the opinion of mental health professionals during the ICD-11 development were conducted by the WPA and WHO in many countries, including Russia.,4 Their results have been used to improve the clinical utility of this classification. In international ICD-11 field studies, Russian specialists have good knowledge of the current ICD-10 and show commitment to classic clinical traditions of Russian psychiatry. ${ }^{5}$

The chapter on mental, behavioral, and neurodevelopmental disorders in ICD-11 is different from that in ICD-10. Changes are related to the title and structure of the chapter, the expansion of the dimensional principle in assessing the duration and severity of symptoms, the inclusion of new categories, and the format of Clinical Descriptions and Diagnostic Guidelines (CDDG). ${ }^{1}$ Preliminary familiarization with the ICD-11 draft by Russian psychiatrists is often accompanied with comments and objections to certain innovations.

Objectives. This online survey was conducted to identify the current views of the Russian psychiatric community on the upcoming implementation of the ICD-11.

\section{METHODS}

\section{Survey design}

This survey was developed and deployed via Google forms. The link was circulated via social networks (the website of the Russian Society of Psychiatrists and WhatsApp professional groups) and then spread using the snowball technique. Data were obtained online from November 20, 2020, to January 9, 2021.

The survey was composed of 14 obligatory questions partly based on the questions from the WPA-WHO global survey. ${ }^{3}$ The questions covered the following blocks of information: sociodemographic characteristics (age, gender, residence, profession, years of clinical experience, and inpatient or outpatient settings); practice of ICD-10 use; familiarity and satisfaction with ICD-11 draft; emotional attitudes toward ICD-11 innovations; general expectations for ICD diagnosis; and evaluation of the usefulness of different diagnostic classification systems (ICD-9, ICD-10, ICD-11, DSM-IV, DSM-5, and RDoC). Participants could provide their feedback by sharing their views, proposals, or claims on the classification systems expressed in an open type of comments. Responses to all questions were mandatory except the last question on narrative feedback.

The results were collected once the respondents pushed the "submit" button. It was made clear that answering all the questions and pushing the "submit" button would be taken as a sign of voluntary consent to share responses. The survey was completely anonymous, and no identifiable personal data or IP addresses were collected. Ethical approval was not obligatory because of the non-interventional online survey research design.

\section{Participants}

A total of 197 responses from medical professionals were collected. A Venn diagram showing the participants' distribution in terms of specialties is presented in Figure 1. Some specialists had two or more work positions (i.e., psychiatrist and psychotherapist, or psychiatrist, psychotherapist, and physician), each specialty was considered unique. Thus, the sum of all specialties exceeded $n=197$. Altogether, 148 defined themselves as psychiatrists, 36 as psychologists, 26 as psychotherapists, 6 as other physicians, and 7 as non-medical specialists.

Only psychiatrists $(n=148)$ were included in this analysis. The majority live in Moscow $(n=59)$ or Saint Petersburg ( $n=13)$, while others were from 51 large Russian/Belarusian/Kazakhstani cities (with all of them speaking Russian). Among them, 54.7\% ( $n=81)$ were males, and 45.3\% ( $n=67$ ) were females. Psychiatrists of different ages participated in the survey, i.e., 20 (13.5\%), 53 (35.8\%), 37 (25.0\%), 28 (18.9\%), and 10 (6.8\%) were <30, $30-40,40-50,50-60$, and $>60$ years old, respectively. The participants had different durations of clinical experience: 4 (2.7\%), <1 year; 17 (11.5\%), $1-5$ years; 30 (20.3\%), 5-10 years; $26(17.6 \%), 10-15$ years; 20 (13.5\%), 15-20 years; and 51 (34.5\%), >20 years. The majority of psychiatrists ( $n=89,60.1 \%$ ) work in outpatient settings, and 58 (39.2\%) work in inpatient settings.

\section{Statistical analysis}

The primary endpoint of this study was to describe the use of ICD-10 in practice, attitude toward ICD-11 innovations, and expectations for the ICD diagnosis 


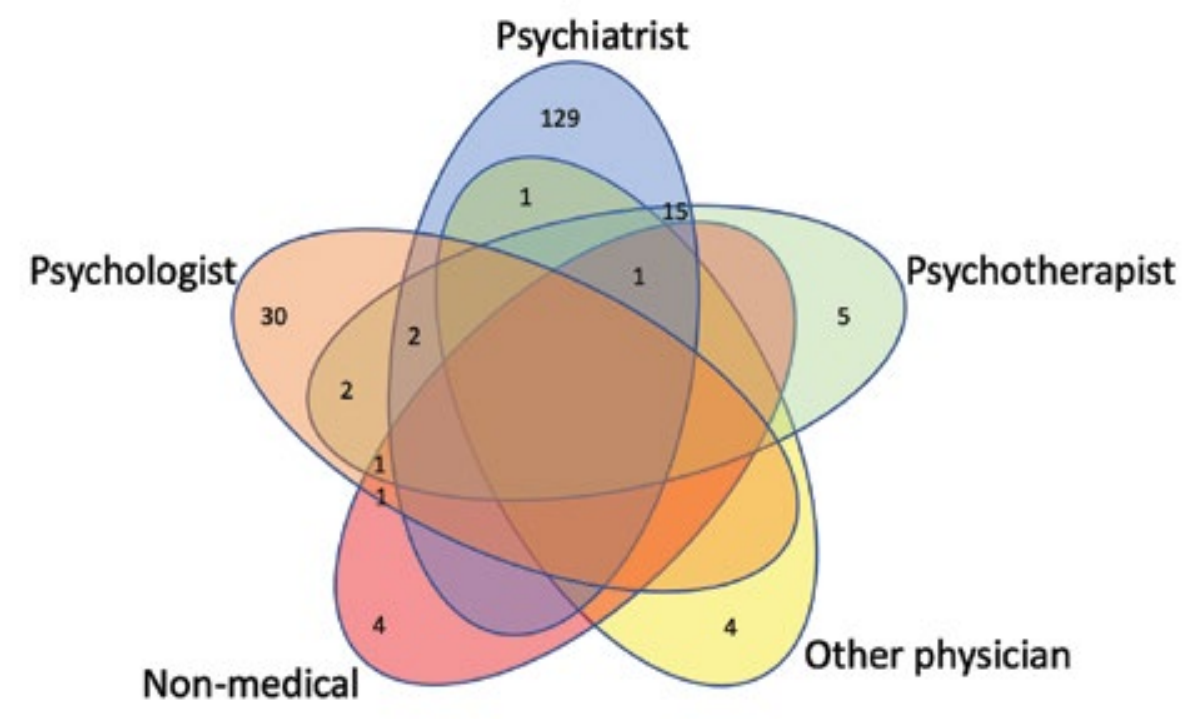

Figure 1. Venn diagram of participant's distribution by the specialties

of mental disorders. Answers were presented in frequency tables. A number of contingency tables were created to characterize the association of responses with other categorial variables (i.e., with gender, age, clinical experience, and clinical settings). These tables were then analyzed via $\chi^{2}$-test with continuity correction or Fisher's exact test if the counts in the cells of the contingency tables were $<5$. A Chi-square test and significance determination by cells were performed. The proximity matrix of responses to each question distribution was created and the percentage of agreement was estimated to evaluate the agreement between responses about the use of ICD-10 in practice and general expectations for a diagnostic classification. Data were statistically analyzed using XLSTAT 2020.5.1 (Addinsoft [2021], New York, USA; https://www.xlstat.com).

\section{RESULTS}

Use of ICD-10 and expectations for ICD diagnosis The majority of the respondents used ICD-10 codes ( $n=144,97.3 \%)$ and diagnostic guidelines $(n=129,89 \%)$ on the everyday basis. Overall, more than half of them considered ICD-10, along with DSM 5 and ICD-11, to be the most clinically useful (Figure 2). Only 79 (53.4\%) were satisfied with ICD-10 diagnosis, 58 (39.2\%) of the participants were partially satisfied, and 11 (7.4\%) were not satisfied.

ICD-10 was most frequently used for a patient's medical record ( $n=140,94.6 \%)$, followed by communication with colleagues ( $n=108,72.97 \%)$, treatment choice and care provision ( $n=90,60.81 \%)$, resolving the patient's social problems $(n=83,56.08 \%)$, clinical research ( $n=78,52.70 \%)$, understanding the patient's condition and prognosis ( $n=77,52.03 \%$ ), communication with patients and their relatives ( $n=58,39.19 \%)$, and other reasons ( $n=28,18.92 \%$; Figure 3 ).

The expectations for the usefulness of ICD diagnosis of mental disorders differed from those for the reported current use of ICD-10. The agreement of responses on the corresponding questions varied from $58.1 \%$ to $89.2 \%$ (Table 1). The largest disagreement between the use of ICD-10 in practice and expectations for ICD diagnosis was observed in the usefulness for "clinical research," followed by the following aspects in a descending order: "understanding of a patient's condition and prognosis," "communication with patients and their relatives," "resolving a patient's social problems," and "treatment 


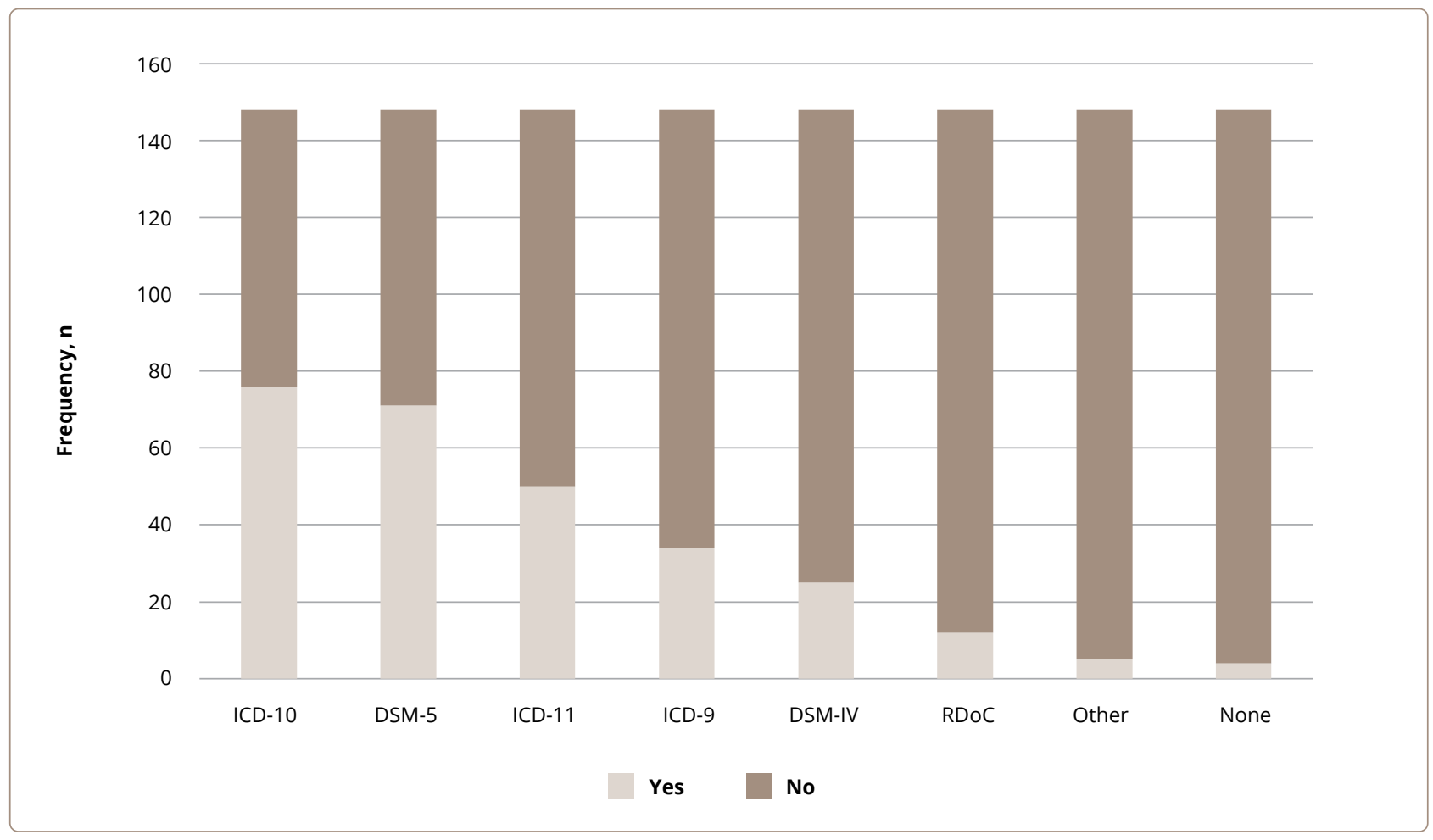

Figure 2. Opinions on clinical utility of different international classification systems

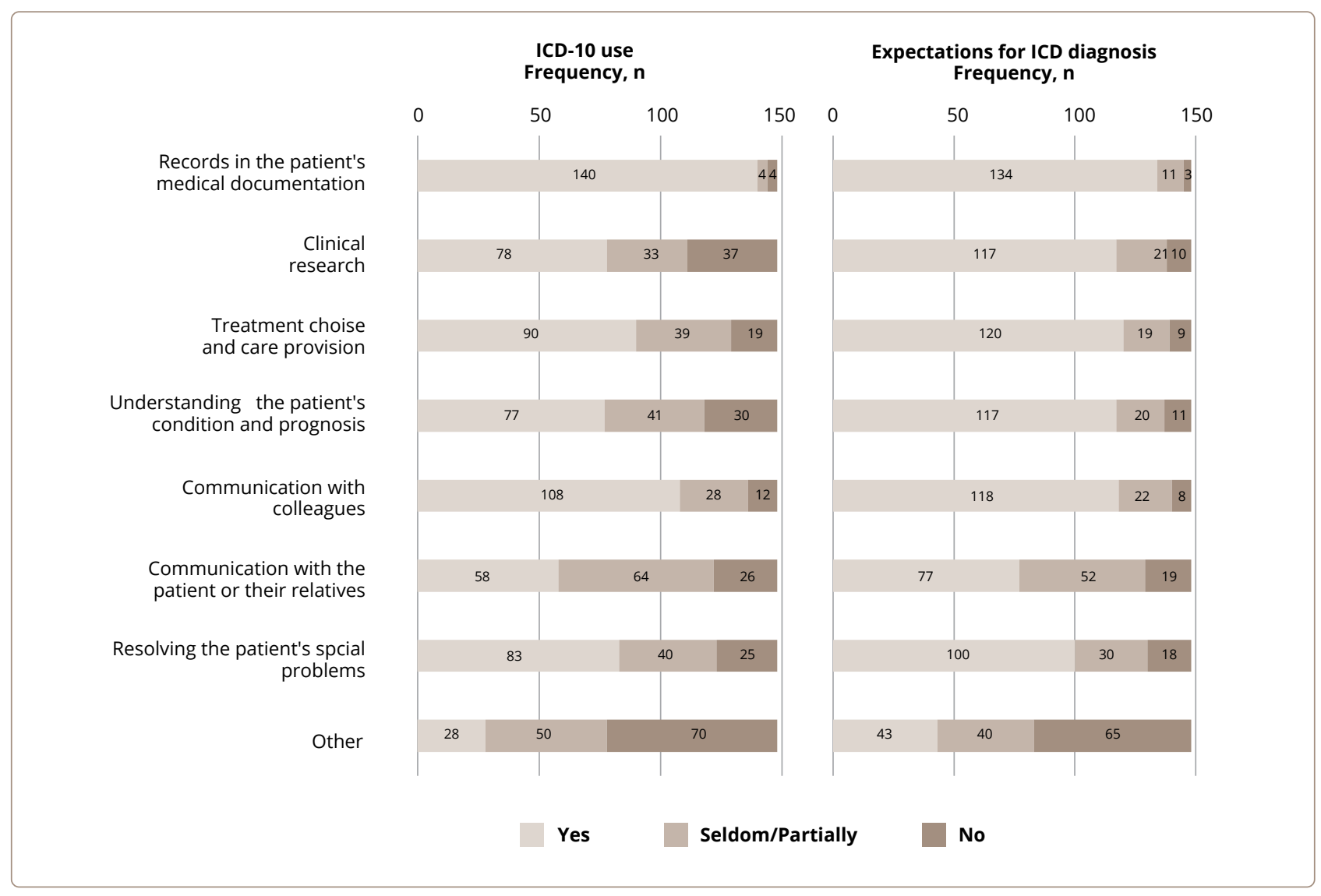

Figure 3. ICD-10 use and expectations for ICD 
Table 1. Distribution of responses relating to use of ICD-10 in practice, matched with expectations of ICD's general usefulness

\begin{tabular}{|c|c|c|c|c|c|c|c|}
\hline \multirow{2}{*}{\multicolumn{2}{|c|}{ Question }} & \multirow[t]{2}{*}{$\begin{array}{l}\text { Answer } \\
\text { Frequency }\end{array}$} & \multicolumn{2}{|l|}{ ICD-10 } & \multicolumn{2}{|c|}{$\begin{array}{l}\text { Expectations for ICD } \\
\text { diagnosis }\end{array}$} & \multirow[t]{2}{*}{ Agreement \% } \\
\hline & & & \multirow{2}{*}{$\begin{array}{l}\text { Proportion } \\
\text { per category }\end{array}$} & \multirow{2}{*}{$\begin{array}{l}\text { Frequency } \\
94.6 \% \\
\end{array}$} & \multirow{2}{*}{$\begin{array}{l}\text { Proportion } \\
\text { per category }\end{array}$} & \multirow[b]{2}{*}{$90.5 \%$} & \\
\hline \multirow{24}{*}{ Used for } & \multirow{3}{*}{$\begin{array}{l}\text { recording in } \\
\text { patient's medical } \\
\text { documentation }\end{array}$} & Yes & & & & & \multirow{3}{*}{$89.2 \%$} \\
\hline & & No & 4 & $2.7 \%$ & 3 & $2.0 \%$ & \\
\hline & & Seldom & 4 & $2.7 \%$ & 11 & $7.4 \%$ & \\
\hline & \multirow[t]{3}{*}{ clinical research } & Yes & 78 & $52.7 \%$ & 117 & $79.1 \%$ & \multirow{3}{*}{$58.1 \%$} \\
\hline & & No & 37 & $25.0 \%$ & 10 & $6.8 \%$ & \\
\hline & & Seldom & 33 & $22.3 \%$ & 21 & $14.2 \%$ & \\
\hline & \multirow{3}{*}{$\begin{array}{l}\text { treatment choice } \\
\text { and care provision }\end{array}$} & Yes & 90 & $60.8 \%$ & 120 & $81.1 \%$ & \multirow{3}{*}{$71.6 \%$} \\
\hline & & No & 19 & $12.8 \%$ & 9 & $6.1 \%$ & \\
\hline & & Seldom & 39 & $26.4 \%$ & 19 & $12.8 \%$ & \\
\hline & \multirow{3}{*}{$\begin{array}{l}\text { understanding of } \\
\text { patient's condition } \\
\text { and prognosis }\end{array}$} & Yes & 77 & $52.0 \%$ & 117 & $79.1 \%$ & \multirow{3}{*}{$62.8 \%$} \\
\hline & & No & 30 & $20.3 \%$ & 11 & $7.4 \%$ & \\
\hline & & Seldom & 41 & $27.7 \%$ & 20 & $13.5 \%$ & \\
\hline & \multirow{3}{*}{$\begin{array}{l}\text { communication } \\
\text { with colleagues }\end{array}$} & Yes & 108 & $73.0 \%$ & 118 & $79.7 \%$ & \multirow{3}{*}{$80.4 \%$} \\
\hline & & No & 12 & $8.1 \%$ & 8 & $5.4 \%$ & \\
\hline & & Seldom & 28 & $18.9 \%$ & 22 & $14.9 \%$ & \\
\hline & \multirow{3}{*}{$\begin{array}{l}\text { communication } \\
\text { with patients } \\
\text { and their relatives }\end{array}$} & Yes & 58 & $39.2 \%$ & 77 & $52.0 \%$ & \multirow{3}{*}{$67.6 \%$} \\
\hline & & No & 26 & $17.6 \%$ & 19 & $12.8 \%$ & \\
\hline & & Seldom & 64 & $43.2 \%$ & 52 & $35.1 \%$ & \\
\hline & \multirow{3}{*}{$\begin{array}{l}\text { resolving patient's } \\
\text { social problems }\end{array}$} & Yes & 83 & $56.1 \%$ & 100 & $67.6 \%$ & \multirow{3}{*}{$70.3 \%$} \\
\hline & & No & 25 & $16.9 \%$ & 18 & $12.2 \%$ & \\
\hline & & Seldom & 40 & $27.0 \%$ & 30 & $20.3 \%$ & \\
\hline & \multirow[t]{3}{*}{ other reasons } & Yes & 28 & $18.9 \%$ & 43 & $29.1 \%$ & \multirow{3}{*}{$77.7 \%$} \\
\hline & & No & 70 & $47.3 \%$ & 65 & $43.9 \%$ & \\
\hline & & Seldom & 50 & $33.8 \%$ & 40 & $27.0 \%$ & \\
\hline
\end{tabular}

choice and care provision." A high agreement between the current practice of ICD-10 and expectations for ICD diagnosis is found in "patients' records" and "communication with colleagues" (Figure 3).

Female respondents were more likely to rely on ICD-10 to understand their patient's condition and prognosis than males $(64.18 \%$ and $41.98 \%$, respectively, Table S1). Psychiatrists aged 60+ years were almost twice less likely to use ICD-10 to make medical records and communicate with colleagues or patients and their relatives $\left(\chi 2=19.688, p=0.012 ; \chi^{2}=20.791, p=0.008\right.$ and $\chi^{2}=26.057, p=0.001$; Table S2 Suppl.). Moreover, they were less likely to expect the usefulness of ICD in preparing medical notes (Table S10). Psychiatrists who work in inpatient settings were less likely to use ICD-10 to communicate with patients and their relatives $(\chi 2=6.653, p=0.036 ;$ Table S4, Suppl.).

\section{Familiarity and satisfaction with ICD-11 draft}

The majority of participants ( $n=137,92.6 \%$ ) were familiar with the ICD-11 draft. In particular, 82 (54.4\%) answered "yes" and 55 (37.2\%) answered "partially" on the question about their knowledge about ICD-11. However, generally, only $40(27.0 \%)$ participants were fully satisfied with ICD-11, and 120 (54.1\%) were partially satisfied.

Among those who were fully familiar with ICD-11 $(n=82)$, $41.5 \%(n=34)$ were fully satisfied, and $43.9 \%(n=36)$ were partially satisfied. 
Most of the participants ( $n=103,69.6 \%$ ) expressed their intention to undergo a special training on the ICD-11 diagnosis of mental disorders. Furthermore, 9 (6.1\%) already participated in such education activities, $8(5.4 \%)$ had no intention to undergo training, and 28 (18.9\%) responded that they would be compelled to participate. The responses of "I want to undergo training," "I don't want to undergo training," "I already participated in such training," and "I shall be pressed to undergo training" among fully and at least partially familiar with ICD-11 were as follows: 60 (73.2\%) and 94 (68.6\%), 6 (7.3\%) and 8 (5.8\%), 7 (8.5\%) and 9 (6.6\%), and $9(11.1 \%)$ and $26(19 \%)$, respectively.

\section{Attitudes toward the ICD-11 innovations}

The question on specific attitudes to ICD-11 changes and innovations were multivariate choices of the following responses: "interest," "concern," "protest," "indifference," or "other attitudes," which were distributed in 99 (66.9\%), $44(29.7 \%), 8(5.4 \%), 16(10.8 \%)$, and 9 (6.1\%) respondents, respectively. A combination of different responses was allowed. Thus, the most common was the simultaneous choice of "interest" and "concern" responses (Figure 4).

The largest proportion of "interest" responses was among psychiatrists who had 5-10 years of practice
(75,0\%). Females were more worried than males toward innovations in ICD-11 ("concern" responses: $38.81 \%$ vs. $22.22 \%, \chi^{2}=4.827, p=0.028$, Table S5 Suppl.). More "protest" responses were given by those who work in inpatient settings $\left(\chi^{2}=4.475, p=0.034\right)$.

On the question about attitude toward ICD-11 innovations among participants who were fully familiar with the ICD-11 draft, the following responses were obtained: "interest", 61 (74.4\%); "concern", 19 (23.2\%); "protest", 3 (3.7\%); "indifference", 4 (4.9\%); and others, $6(7.3 \%)$. Among those who were at least partially familiar with ICD-11 $(n=137)$, the distribution of answers was as follows: 94 (68.6\%), 41 (29.9\%), 15 (10.9\%), 7 (5.1\%), and $7(5.1 \%)$, respectively (Figure 5). Among 11 psychiatrists who were not familiar with ICD-11 draft, the following answers were observed: "interest", 5 (45.5\%); "concern", 3 (27.3\%); "protest" and "indifference", 1 (9.1\%); and other attitudes, 2 (18.2\%).

\section{Respondents' views on the classification of mental disorders}

Views and comments on the classification of mental disorders freely formulated by the participants were reported by 113 of 197 respondents. The responses containing the suggestions, recommendations, claims,

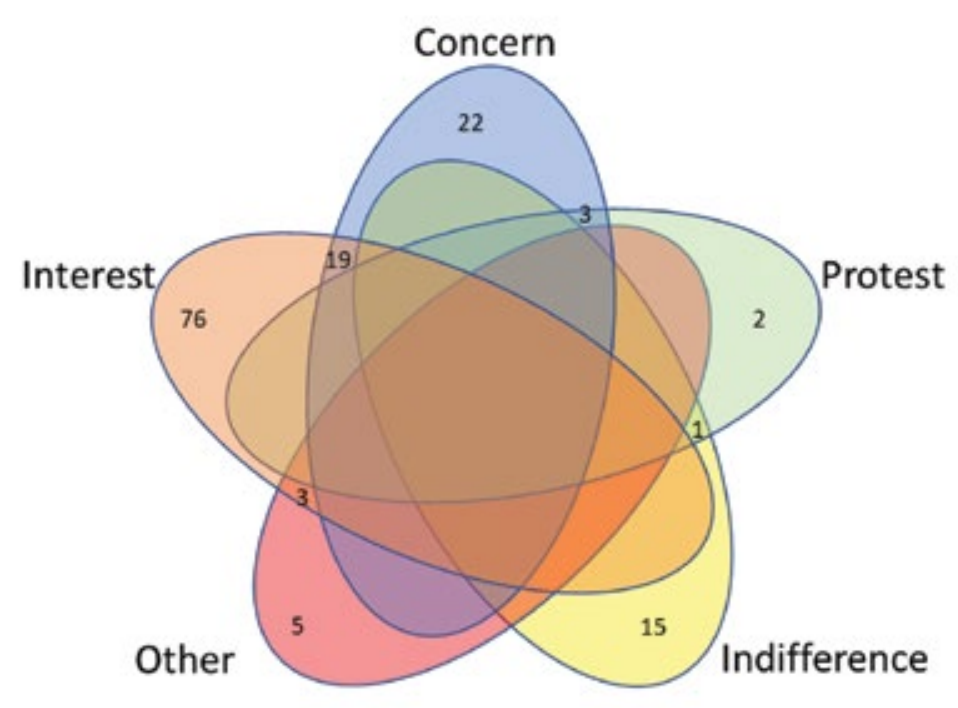

Figure 4. Venn diagram of emotional attitudes towards ICD-11 
or other comments of the respondents were separately subjected to narrative analysis. Through this analysis, four types of comments provided by the respondents could be distinguished depending on their basic general views on the diagnostic classification of mental disorders. They may be figuratively named as follows: "traditionalist," "nihilist," "practitioner," and "reformer." The contingency tables of the types of narrative responses in terms of age, years of clinical practice, work settings, ICD-10 use, and attitude toward ICD-11 innovations are presented in Table S13 (Suppl.).

The "traditionalist" type of comments $(n=39,34.5 \%)$ was characterized by "diagnostic conservatism." The respondents provided predominantly conservative comments expressed in classic psychopathological views on psychiatric diagnosis. They tended to deny modern trends in diagnosis, requested to preserve old school traditions in the conceptualization of mental disorders, and adhered to ethiopathogentic," "nosological" approach to diagnostic classification. Some of them were against the "psychologization" of psychiatry, while others mainly advocated the priority of the national traditions of systematic psychopathology. For example, "In my opinion, it is very simplified, and the classic approach is lost." "Classifications should be written by doctors, not psychologists." "It is necessary to take into account and combine it with the national classification of mental disorders."

The "nihilist" type ( $\mathrm{n}=9$ 9, 8.0\%) was characterized by "diagnostic nihilism" expressed in negativistic comments. It was the smallest group with total denial or views on the worthlessness of diagnostic guidelines and classification improvement. They perceived the ICD-11 implementation as unnecessary difficulties. For example, "Artificiality, an attempt to draw boundaries where there are none"; "Constant renaming confuses the professionals; it's time to stop the "classification games."

The "practitioner" type was characterized by "diagnostic practicism" ( $n=31,27.4 \%)$ with practically oriented comments focused on the clinical utility and usefulness of the new classification. The respondents were looking forward to having a convenient practical instrument for the diagnosis of mental and behavioral disorders. They were also very keen to undergoing an appropriate training. For example, "It is necessary to study, to implement in the work, and to move forward with time." "There are no complaints; I would like to receive additional training on ICD-11 for the diagnosis of mental disorders in the near future."

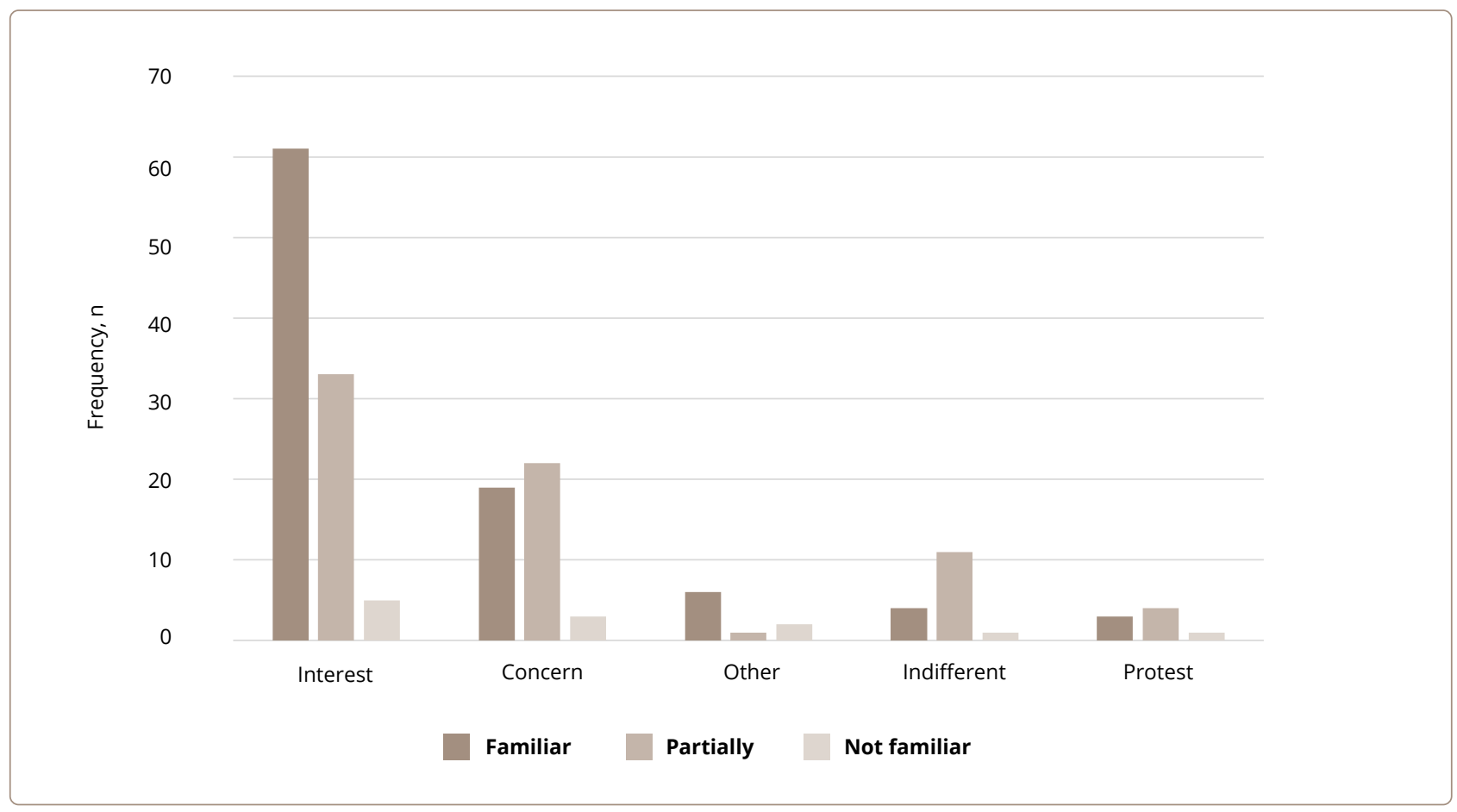

Figure 5. Emotional attitudes towards ICD-11 depends on familiarity with ICD-11 
The "reformer" type was characterized by "diagnostic reformism" ( $n=34,30.1 \%)$. The respondents expressed through constructive comments and suggestions the need to optimize the classification, add new categories and blocks of disorders (e.g., a special group of gerontological mental disorders or organic disorders in children), and transform the categories of "others" or "unspecified" disorders. For example, "It is advisable to update the classification regularly," and "I would prefer to see a full, separate section on child psychiatry."

These types of comments also indirectly reflected a specific attitude to the ICD-11 implementation.

\section{Associations between the types of comments and} the characteristics of respondents

The statistical analysis revealed a set of significant associations between these particular types of comments and other responses or characteristics of respondents.

Thus, the psychiatrists either older than 50 years or having longer clinical practice (>20 years) more likely provided conservative comments $(50 \%$ and $48.9 \%$, respectively) than the others (less than $35 \%$ for every other group).

The psychiatrists working in hospitals were more prone to give practically oriented comments ( $31.1 \%$ vs. $20.5 \%$ of those working in outpatient settings).

Although almost all psychiatrists used ICD-10 codes in their work, psychiatrists who gave negativistic or conservative comments ( 1 and 2 responses, respectively) refused to apply the ICD-10 diagnostic guidelines.

The distribution of the satisfaction with the ICD-11 draft in terms of the type of comments significantly differed $\left(X^{2}=23.998, p=0.001\right)$. Specialists who gave conservative and constructive comments more frequently were not satisfied or partially satisfied with ICD-10 diagnostics (20 of 39 and 20 of 34, respectively, compared with 3 of 9 and 14 of 31 of those who provided negativistic and practically oriented comments).

Dissatisfaction with the ICD-11 draft $(n=24)$ was more evident among those who gave conservative comments $(n=15,62.5 \%)$. Conversely, the majority $(n=14,53.8 \%)$ of those who were satisfied with ICD-11 $(n=26)$ provided constructive comments, and this distribution was statistically significant. The "protest" responses to the question on attitude toward ICD-11 innovations had significantly independent distribution $\left(\chi^{2}=16.807\right.$, $p=0.001)$. All "protest" responses $(n=7)$ were presented by the psychiatrists who gave either conservative ( $n=4,57.1 \%)$ or negativistic $(n=3,42.9 \%)$ comments.

The readiness to undergo additional trainings on ICD-11 had independent distribution as indicated by the type of comments $\left(\chi^{2}=17.510, p=0.041\right)$. The responses "I don't want to undergo a training" and "I'll be pressed to undergo a training" were more frequently given by those who had conservative comments: 5 of $6(83.3 \%)$ and 10 of $20(50 \%)$, respectively.

Among the questions on the purpose of ICD only the responses "understanding the patient's condition and prognosis" and "resolving the patient's social problems" showed a significantly independent distribution $\left(\chi 2=15.012, p=0.020\right.$ and $\chi^{2}=21.166$, $p=0.002$, respectively). Only those who gave conservative $(\mathrm{n}=8)$ and negativistic $(\mathrm{n}=2)$ comments responded "no" to the question on the usefulness of ICD for understanding a patient's condition and prognosis. Psychiatrists who gave conservative and negativistic comments more frequently denied the possibility of using ICD to resolve the patient's social problems: 7 of 39 (17.9\%) and 2 of $9(22.2 \%)$, respectively. Conversely, psychiatrists who gave constructive and practically oriented comments agreed almost twice more frequently than those who gave conservative and negativistic comments with the use of ICD for addressing the patient's social problems: 31 of $34(91.2 \%)$ and 25 of 31 (80.6\%) vs. 19 of $39(48.7 \%)$ and 4 of $9(44.4 \%)$, respectively.

\section{DISCUSSION}

The results had similarities and differences with international studies on attitudes toward mental disorders classification. Thus, communication among clinicians followed by informing treatment and management decisions were reported as the two main uses of a diagnostic classification system by more than 4,000 psychiatrists from 44 countries as respondents of the WPA-WHO global survey in $2011 .^{3}$ While in our survey, the records in patient's documentation and communication among clinicians, were responded as the two leading purposes to the use of ICD-10 in contrast to understanding the patient's condition or prognosis and communication with patients or their relatives which were of minimal rating. This finding corresponds to the results of another global survey involving 1,700 respondents from 92 countries in 2015 as a part of the development of the ICD-11 classification of mental and 
behavioral disorders. ${ }^{4}$ The classification systems reported by global respondents were most frequently used for administrative or billing purposes. International field studies on the clinical utility of the ICD-11 diagnostic guidelines also showed that the participating clinicians evaluate the guidelines as less useful for treatment choice and prognosis assessment than for communicating with other health professionals. ${ }^{2}$ Meanwhile, in our survey the respondents believed that the ICD diagnostic in general should be extended to facilitating clinical research and conceptualizing disorders.

The attitudes toward ICD-11 expressed by the respondents were of a debatable character. Being positive in general, specific attitudes to the forthcoming classification which have been also expressed in the narrative comments, were of more complex content including not only an interest, but along this also a concern and even a discontent. The typical trends of views on ICD diagnosis - conservative, constructive, practically oriented or negativistic ones - were associated with different factors, such as years of clinical practice, work settings, experience in ICD-10 use, and level of knowledge about ICD-11 innovations. The attitudes also contributed to the willingness to undergo the necessary training.

The tendency to follow "diagnostic conservatism" was mostly inherent in psychiatrists aged $>50$ years with $>20$ years of clinical practice. This group was the only one that refused to use ICD-10 diagnostic guidelines (5.26\%). They less frequently applied ICD-10 to research work and were characterized by the lowest percentage of knowledge about the ICD-11 draft among the groups. They were more frequently unsatisfied with the ICD-11 draft, had greater protest to ICD-11 innovations, and denied to undergo further trainings on ICD-11.

The tendency to exhibit "diagnostic reformism" was generally inherent in specialists aged 30-40 years with 5-10 years of clinical practice. They were represented by the highest proportion of those who use the ICD-10 for different purposes mentioned in the survey. The respondents who gave constructive comments were generally familiarized and mostly satisfied with ICD-11 draft. They also showed greater interest and less concern on ICD-11 innovations. Moreover, they were interested in further education on ICD-11.

The tendency to have "diagnostic practicism" was common among young or middle-aged specialists (below 30 years and from 40 years to 50 years) with a short duration of clinical practice (1-5 years). This group was the only one with females who were slightly over-represented compared with males (54.84\%). This group included a higher proportion of psychiatrists from outpatient settings. The psychiatrists who gave practically oriented comments were represented by specialists who had positive experience on ICD-10 use for any purposes. They felt quite acquainted and mostly satisfied with the ICD-11 draft. They showed greater interest in ICD-11 innovations and were highly motivated to have further education on ICD-11.

The tendency to have diagnostic "nihilism" was the rarest. It was observed mainly in specialists aged $>60$ years or, having 10-15 years of clinical practice, and working in inpatient settings. They accounted for the highest proportion of those who preferred ICD-10 for limited formal purposes. Moreover, they showed higher concern and greater protest to ICD-11 changes.

Therefore, a general negative attitude toward ICD-11 related to discontent or protest was more typical among those who had a longer clinical practice and expressed traditionalist views. They were also more critical of the classification of mental disorders and did not consider it to be useful for understanding the patient's condition and care provision or resolving the patient's social problems. Conversely, respondents of more younger age perceived that ICD could be beneficial to solving a wider range of tasks other than formal coding or communicating with colleagues. The majority of respondents preferred to have a classification of mental disorders that could be more acceptable for clinical research, conceptualization of diseases, or communication with patients or their relatives.

A positive attitude was associated with interests in ICD-11 and intention to undergo further special education. Moreover, younger participants or those with less clinical experience were inspired to face ICD-11 with more interest and willingness to participate in appropriate training. This observation corresponded to the results of the online survey conducted by the WPA Early Career Psychiatrists Section in 2019.6

The positive expectations of the surveyed participants corresponded to a better familiarity with the ICD-11 draft. The majority of the respondents who were familiar with the ICD-11 draft were satisfied. The more familiar 
the psychiatrists were with the ICD-11 draft, the more interested and less concerned they were on ICD-11 implementation.

\section{Limitations}

The limitations of this study are determined by the type of online survey, which was conducted in a Google form. Free access included random responses, although the link to the survey was in the top page of the professional website for 2.5 months. The intention to respond to the survey could be an additional characteristic of participant selectivity. A relatively small sample also raised questions on the reliability of the obtained data disseminated to the entire professional community. Nevertheless, the identified trends were consistent with the oral comments expressed in the presentations of specialists during meetings or lectures on ICD-11.

\section{CONCLUSION}

This survey reveals the main tendencies in the attitudes and expectations of the participating Russian psychiatrists on the forthcoming ICD-11 implementation and diagnostic classification system in general.

More than half of the respondents look forward to facing ICD-11 with positive expectations, whereas some of them with a longer clinical experience foresee some difficulties or express discontent.

Interests in ICD-11 are related to the degree of familiarity with it. As such, familiarizing the professional community with ICD-11 innovations becomes challenging because it requires the correct translation of the classification and diagnostic guidelines and an appropriate education provision. The majority of psychiatrists participating in the survey plan to undergo further training on ICD-11 diagnosis.

The participants prefer to use the ICD diagnosis of mental disorders in a more extended scope. Specifically, they want to apply this diagnosis not only to statistic or formal purposes, but also for the clinical research and understanding of a patient's condition, as well as for practically oriented use to improving contact with patients or for better care provision.

The psychiatrists in this survey have different attitudes toward ICD-11 and its diagnostic trends. They reflect a diversity of opinions on the classification of mental disorders in the Russian professional community. As such, these differences should be considered in the development of training programs that address professionals' expertise and clinical experience. At least three kinds of ICD-11 education-targeted programs should be considered. (1) Medical students and trainees with lack of clinical experience should be trained in terms of the use of the diagnostic instrument; (2) Clinicians who are qualified in ICD-10 should be trained so that they can appropriately transfer to ICD-11; and (3) The format of continuous medical education should be extended to improve professional qualification regularly.

This survey can be useful for the appropriate organization of ICD-11 promotion campaigns. Such campaigns should focus on the clinical utility of this classification and its evident-based advantages, which have been confirmed by the results of international field studies.

Authors contribution: Maya A. Kulygina: survey design, analysis of results, article writing; Timur S. Syunyakov: statistical data processing, analysis of results, article writing; llya A. Fedotov: data collection, narrative analysis, editing; George P. Kostyuk: conceptualization, supervision.

Funding: The research was carried out without additional funding.

Conflict of Interest: The authors report no conflicts of interest.

\section{Correspondence to:}

\section{Maya A. Kuligina}

mkulygina@yandex.ru

\section{For citation:}

Kulygina MA, Syunyakov TS, Fedotov IA, Kostyuk GP. Toward ICD-11 implementation: attitudes and expectations of the Russian psychiatric community. Consortium Psychiatricum. 2021;2(2):23-34. doi:10.17816/CP80

\section{References}

1. Reed GM, First MB, Kogan CS, et al. Innovations and changes in the ICD-11 classification of mental, behavioural and neurodevelopmental disorders. World Psychiatry. 2019;18(1):3-19. doi:10.1002/wps.20611

2. Reed GM, Keeley JW, Rebello TJ, et al. Clinical utility of ICD-11 diagnostic guidelines for high-burden mental disorders: results from mental health settings in 13 countries. World Psychiatry. 2018;17(3):306-315. doi:10.1002/wps.20581 
3. Reed GM, Mendonca Correia J, Esparza P, Saxena S, Maj M. The WPA-WHO Global Survey of Psychiatrists' Attitudes Towards Mental Disorders Classification. World Psychiatry. 2011;10(2):118131. doi:10.1002/j.2051-5545.2011.tb00034.x

4. First MB, Rebello TJ, Keeley JW, et al. Do mental health professionals use diagnostic classifications the way we think they do? A global survey. World Psychiatry. 2018;17(2):187-195. doi:10.1002/wps.20525
5. Kulygina M, Krasnov V, Ponisovskiy P, Keeley J, Reed G. ICD11 Psychotic Disorders: Preliminary Results of the Casecontrolled Studies and the Russian Opinion. Eur Psychiatry. 2020;41(S1):S227-S227. doi:10.1016/j.eurpsy.2017.01.2227

6. Pinto da Costa M, Ng RMK, Reed GM. International classification systems: views of early career psychiatrists. World Psychiatry. 2021;20(1):148-149. doi:10.1002/wps.20834 